\title{
Postsecondary Transition Programs for Underprepared Writers
}

\author{
Christine M. Antonetti ${ }^{1, *}$ \\ ${ }^{1}$ School of Arts \& Science, Farmingdale State College, 2350 Broadhollow Road, Farmingdale, NY 11735, USA \\ *Correspondence: School of Arts \& Science, Farmingdale State College, 2350 Broadhollow Road, Farmingdale, NY \\ 11735, USA. Tel. 1-631-420-2082: E-mail: antonec@farmingdale.edu \\ Received: September 13, 2017 \\ Accepted: September 25, 2017 Online Published: November 26, 2017 \\ doi:10.5430/jct.v6n2p113 \\ URL: https://doi.org/10.5430/jct.v6n2p113
}

\begin{abstract}
There is a large population of students who enter postsecondary institutions underprepared in the area of writing, which can negatively affect their academic success in various disciplines. Lack of alignment between secondary and postsecondary education writing curricula is a common cause of why students are underprepared in writing. Identifying gaps in writing when transitioning from secondary to postsecondary institutions is critical in creating appropriate writing support programs which better prepare students for academic success. Moreover, in order to facilitate successful postsecondary writing outcomes, proactive writing interventions (transition programs) between secondary and postsecondary institutions can be implemented to generate a positive impact on students' ability to write, thereby leading to greater academic success.
\end{abstract}

Keywords: underprepared; postsecondary writing; transition programs; writing difficulty; academic support; writing support; remedial writing

\section{Introduction}

Weak writing skills are common among most students beginning in their elementary years and carrying over into postsecondary years. Despite the importance of writing, many students do not write well enough to meet the demands of school, and college instructors estimated that $50 \%$ of high school graduates are not prepared for college-level writing demands (Graham \& Perin, 2007).

Some methods of writing taught in secondary education differ from the style needed for success in postsecondary education. Necessary techniques in writing that prepare students for success in postsecondary institutions and in the workforce should include (a) organizing writing tasks, (b) generating ideas about the writing topics, and (c) producing final written products that are coherent and organized. Research on effective postsecondary writing instruction focuses on the quality of writing content rather than writing mechanics as seen in secondary classrooms (Baker, Chard, Ketterlin-Geller, Apichatabutra, \& Doabler, 2009). Additionally, Baker et al. (2009) identify necessary qualities of successful academic writing to include (a) organizing information and ideas, (b) implementing rhetorical structures, and (c) engaging an audience.

The identification of gaps in writing when transitioning from secondary to postsecondary institutions will assist in creating supportive transitional writing programs. The purpose of the transitional writing program is to (a) minimize the number of incoming first-year students who take a non-credit bearing remedial writing course and (b) better prepare incoming first-year students for postsecondary academic writing.

In order to identify gaps in writing when transitioning from secondary to postsecondary institutions, the following questions should be addressed:

(a) What are weak writing skills of traditional first-year students entering postsecondary institutions?

(b) Which areas from the transitional writing program were incorporated and reflected in the revised essays?

\subsection{Writing Curricula}

Lack of alignment between secondary and postsecondary education writing curricula is still a common cause of students who are underprepared in writing. According to Fanetti, Bushrow and DeWeese (2010), since high school education is designed to be standardized and quantifiable whereas college education is designed to be theoretical, the 
result is that students leave high school unprepared for college. Baker et al. (2009) found that ineffective writing instruction methods in secondary education writing curriculums generally consist of (a) combining simple sentences into more complex sentences, (b) students writing substantial amounts of text with minimal guidance from the teacher, and (c) methods that had students attempt to emulate features of good writing they found in writing of others. Currently, most students are taught within a framework to write analytic essays, comparing and contrasting two or more concepts, objects, people, or events (Baker, et al., 2009). Therefore, ineffective methods direct little attention to critical components of writing in postsecondary disciplines which include (a) organizing information and ideas, (b) writing legibly, (c) implementing rhetorical structures, and (d) engaging an audience (Baker et al., 2009).

Sacco (2014) identifies that poor writing skills pose academic problems when transitioning students into postsecondary institutions. Eventually, when students face extensive difficulties in writing, a subject required within most postsecondary disciplines, obtaining academic assistance is necessary for program completion and success. In postsecondary institutions, students share similar writing challenges with using proper grammar, organizing the essay, interpreting the requirements, answering the assignment question, and developing ideas (Robinson, 2009; Baker et al. 2009).

\subsection{Academic Writing Practices}

Academic writing is an expectation across the disciplines in most postsecondary institutions, yet many students in the United States have very poor writing skills (Baker et al., 2009). Writing difficulties will result in inadequate knowledge of subject content that will hinder discipline learning in postsecondary institutions and in underachievement of basic skills, ultimately leading to high postsecondary attrition rates (Hong, Ivy, Gonzalez \& Ejrensberger, 2007). Although reactive techniques to poor writing skills such as remedial writing courses are present, there seems to be a lack of proactive techniques, such as postsecondary transition programs, for underprepared students.

\subsection{Secondary Writing Practices}

Baker et al. (2009) imply most writing lessons in elementary and secondary institutions are approached passively where writing is incorporated with reading, and structure is not emphasized. Common writing practices in secondary education classrooms consider writing instruction somewhat passively by having students read extensively and encouraging them to apply to their own writing what they observed in the writing of others (Baker et al., 2009). Research indicates the methods do not help students become better writers; instead, the research on effective writing instruction has focused on the quality of writing content rather than writing mechanics, such as grammar and spelling. Applebee and Langer (2011) identify that writing in secondary institutions is short and does not provide students with opportunities to think through issues, show depth of their knowledge or go beyond what they know in making connections and raising new issues.

\subsection{Postsecondary Writing Practices}

Baker et al. (2009) identify necessary qualities of successful academic writing include (a) organizing information and ideas, (b) writing legibly, (c) implementing rhetorical structures, and (d) engaging an audience. Therefore, regarding writing instruction, a common goal is to teach students how to organize writing tasks, generate ideas about the writing topics, and produce final written products that are coherent and organized and that can be used in various courses. Baker et al. (2009) also found that writing interventions in educational settings had a positive impact on students' perceptions of their own abilities to write effectively, leading to academic success by strengthening writing skills.

\section{Method}

Qualitative research methods were the best approach to identify and obtain information regarding participant outcomes because the data analysis process was an effective method of discovery when measuring improvement. Since participant responses did not include statistics, the information gathered from participants was coded, grouped, and analyzed to describe the central phenomena (Creswell, 2013).

The study focused on incoming first-year students enrolled at a four-year public postsecondary institution who participated in the TRiO program. TRiO is a support service program funded by the U.S. Department of Education that provides academic support and assistance to 180 eligible students per year at the institution. All students enrolled in ASAP must be a U.S. citizen of permanent residence and meet at least one of the following criteria: (a) be first-generation college, (b) be low-income according to the U.S. Department of Education guidelines, or (c) have documented disability ("TRiO Eligibility Criteria," 2017). 


\subsection{Participants \& Recruitment}

Students enrolled in the TRiO were required to participate in a two-week academic development program over the summer, before entering the postsecondary institution. One of the developmental courses included academic writing. The students participated in a postsecondary academic writing program for a total of six hours (three hours per week for two weeks). The writing program was conducted through the postsecondary institution's writing center and taught by the Writing Center staff. The staff included adjunct faculty in the postsecondary English and Professional Communications Departments, as well as the Director of the Writing Center. The program design addressed gaps between secondary and postsecondary academic writing based on Sacco's (2014) writing transition curriculum. Each student was given an essay assignment to complete before the TRiO program began (Appendix A).

The purpose of the written assignment was multi-faceted. First, a draft assignment allowed students to effectively use the revision process since the students were to incorporate the writing techniques discussed in class to their draft for homework. Second, students could evaluate their own strengths and weaknesses in writing based on instructor feedback on the initial essay.

All of the TRiO students were informed about the research project and were told participation was voluntary with no impact on their grades. The students were also given a consent form (Appendix B) and were told to review the form and to return it (signed or unsigned) before the end of the course.

\subsection{Study Design}

All of the students (participants and non-participants) received grades on their initial essays based on postsecondary writing standards and expectations (see Transitional Course Model 2.3). Grading students on a postsecondary standard allowed students to gauge their postsecondary writing levels and allowed them to focus on specific areas needing improvement. The initial draft acted as an individual starting point for postsecondary writing. Students were able to apply new concepts to their initial drafts for improvement by revising the essays after each session. All of the graded, unrevised essays were copied and stored in a locked cabinet until the writing program ended. The original graded essays were returned to the students on day two of the program.

Prior to the last day of class, all of the students revised the essays and submitted final copies of the initial essays that reflected and incorporated concepts from the writing program on the last day of class. The final copies reflected revisions that incorporated postsecondary concepts into the original essays. The second set of essays was also graded, copied, and stored with the initial essays. The original final copies were also returned to the students.

Fifteen randomly selected participants were chosen for the study. The remaining essays from consenting participants and non-participants were destroyed. Participants were assigned a number, and all consent forms were stored separately to protect their identities. Each participant's essay grades were recorded and destroyed. Both essays from each participant were assessed and evaluated based on the same rubric to measure the level of improvement after students completed the academic transition program in writing.

Based on the findings as seen in Table 1, the content for the transitional summer course was created.

Table 1. Transitional Course Outline

\begin{tabular}{|c|c|c|}
\hline Day & Subject Addressed & Covered Content \\
\hline Day 1 & Overview of Program & $\begin{array}{l}\text { The role of the academic writer, writing expectations, and } \\
\text { secondary vs. postsecondary writing. }\end{array}$ \\
\hline Day 2 & The Writing Process & $\begin{array}{l}\text { Getting started, approaches to writing, and analyzing vs. } \\
\text { summarizing. }\end{array}$ \\
\hline Day 3 & Organizing and Outlining & $\begin{array}{l}\text { Dissecting assignments, writing in sections, outlining, and } \\
\text { consistency in presenting material }\end{array}$ \\
\hline Day 4 & Creating Content & $\begin{array}{l}\text { Content organization, using and presenting evidence, } \\
\text { plagiarism, and citations. }\end{array}$ \\
\hline Day 5 & Paragraph Structure & Revising paragraphs, sentences, word choice and transitions. \\
\hline Day 6 & Implementing Rhetorical Structures & Introductions, conclusions, and assembling the essay. \\
\hline
\end{tabular}




\section{Results}

Each participant was required to attend every class in its entirety, write one initial essay, and rewrite the essay applying concepts learned to the already drafted essay. Students received two grades: an initial grade and a revised grade. The revised essays were evaluated to determine whether the issues were corrected.

Although 15 random participants were selected, only nine participants qualified for the research. Six of the participates were disqualified from the study because (a) they had incomplete final drafts, (b) they handed in the initial draft after the course began, thus potentially applying new concepts into the initial draft, and/or (c) they did not attend every session in full. Students who had incomplete final drafts failed to hand in a second paper or failed to revise the second paper, and students who had incomplete initial drafts handed the initial draft in after the course began, therefore already potentially applying new concepts into the initial draft. Moreover, some students did not attend every class and missed content needed to revise their initial issues. Using the disqualified participants would provide an inaccurate perception of the underprepared student's ability.

Identified areas of writing weaknesses based on the initial essays of the participants were categorized into groups that were identified by Sacco (2014) (Table 2).

Table 2. Identification of Weaknesses

\begin{tabular}{|c|c|}
\hline Postsecondary Writing Difficulties & Student Writing Issues \\
\hline \multirow[t]{2}{*}{ Organizing Content } & a. Unorganized ideas \\
\hline & b. Misplaced content \\
\hline \multirow[t]{5}{*}{ Creating Content } & c. Unclear main ideas \\
\hline & d. Incorrect content in introduction \\
\hline & e. Vague generalizations \\
\hline & f. Lacks explanation of ideas \\
\hline & g. Lacks support/discussion \\
\hline Getting Started & Not identified \\
\hline \multirow[t]{2}{*}{ Understanding Requirements } & h. Did not follow requirements \\
\hline & i. Provided incorrect information \\
\hline \multirow[t]{7}{*}{ Grammar, structure } & j. Word choice \\
\hline & k. Conversational language \\
\hline & 1. Grammatical errors \\
\hline & m. Syntax \\
\hline & n. Poor sentence structure \\
\hline & o. Choppy sentences \\
\hline & p. Wordiness \\
\hline
\end{tabular}

Initial issues were identified for each participant, along with improved areas and areas that still needed improvement (Table 3). 
Table 3. Participant Results

\begin{tabular}{clclcc}
\hline Participant & \multicolumn{1}{c}{ Initial Issues } & Initial Grade & Improved Areas & Revised Grade & $\begin{array}{c}\text { Areas not } \\
\text { Improved }\end{array}$ \\
\hline 1 & A, B, C, D, G, H, P & Incomplete & A, B, C, D, G, H & A- & P \\
2 & C, D, J & B+ & C, D, J & A & - \\
3 & C, D, K, M, N, O & C- & C, D, K, M, O & A- & N \\
4 & A, D, F, G, J, K, L, M, N & D & A, D, F, G, K, N & B & J, L, M \\
5 & A, D, J & B- & A, D, J & A & - \\
6 & B, F, G, I, J, K, P & C- & B, F, G, I, K, P & A- & J \\
7 & A, B, D, E, G, H & C- & A, B, D, G, H & B+ & E \\
8 & A, B, D, P & B & A, B, D, P & A & - \\
9 & A, B, E, H, I, J, L & Incomplete & A, B, E, H, I & B+ & J, L \\
\hline
\end{tabular}

\subsection{Hypothesis 1}

What are weak writing skills of traditional first-year students entering postsecondary institutions? The participants demonstrated multiple areas of difficulty and shared common writing issues upon entering the course as seen in Table 4 .

Table 4. Student Initial Errors

\begin{tabular}{lc}
\hline \multicolumn{1}{c}{ Initial Error } & Number of Participants \\
\hline Unorganized ideas & 6 \\
Misplaced content & 5 \\
Unclear main ideas & 3 \\
Incorrect content in introduction & 6 \\
Vague generalizations & 2 \\
Did not explain ideas & 3 \\
Lacked support /discussions & 4 \\
Did not follow assignment requirements & 2 \\
Provided incorrect information & 2 \\
Poor word choice & 5 \\
Conversational language & 3 \\
Grammatical errors & 2 \\
Text talk & 2 \\
Poor sentence structure & 2 \\
Choppy sentences & 2 \\
Wordiness & 3 \\
\hline
\end{tabular}

The most common errors shared by the majority of participants (about $45-65 \%$ of participants) based on the initial draft included (a) unorganized ideas, (b) misplaced content, (c) incorrect content in the introduction, (d) lack of support or discussion, and (e) poor word choice. Applebee and Langer (2011) identify that writing difficulty is present because writing in typical classrooms is dominated by tasks in which the teacher does all the composing, and students are left to fill in missing information or just write the particular information the teacher is seeking. According to Baker et al., (2009) postsecondary students have issues in writing because they fail to plan and to organize their writing, and that students who experience more serious deficits in writing on a postsecondary level experience difficulty in expository writing related to the process including (a) planning, (b) drafting, (c) monitoring, (d) revising, and (e) organizing. Many participants in the study struggled with these processes.

About $22-33 \%$ of participant papers contained (a) unclear main ideas, (b) vague generalizations, (c) lack of idea explanation or underdeveloped ideas, (d) failure to follow assignment requirements, (d) incorrect information, (f) conversational language, (g) grammatical errors, (h) text talk, (i) poor sentence structure, (j) choppy sentences, and (k) wordiness. 


\subsection{Hypothesis 2}

Which lessons of the writing program were incorporated and reflected into the revised essay? Although all participants showed improvement and incorporated new concepts into their essay, some still needed to improve in areas. Some areas that still needed improvement included (a) vague generalizations, (b) word choice, (c) grammatical errors, (d) text talk, (e) poor sentence structure, and (f) wordiness. The majority of the errors not corrected were reviewed during day 5 , and were not repeatedly covered throughout the course, as was the content from days $1-4$.

\subsection{Remedial and Non-Remedial Placements}

Upon entering the postsecondary institution, all incoming first-year students placed either in a credit bearing English (EGL) composition course (EGL 101) or in a non-credit bearing English remedial writing course (EGL 097). One student enrolled in the summer transition program, who took the EGL 101 equivalent in high school, was placed in a literature course (EGL 102). All 27 students enrolled in the summer transition program (participants and non-participants) were given the first-year English diagnostic test at the end of the course.

\subsubsection{Student Placement before Transitional Course}

All of the TRiO students were registered for an English course before they entered the summer transition program. The postsecondary institution's admissions department placed incoming students into the postsecondary English course based on their performance in a high school English course or based on the written portion of the SAT.

- Number of students initially placed in EGL 097: 8

- Number of students initially placed in EGL 101: 18

- Number of students initially placed in EGL 102: 1

\subsubsection{Student Placement after Transitional Course}

After completing the transitional writing program, all students took a diagnostic test provided by the postsecondary institution's English department. The chairperson of the department graded all of the diagnostic tests, and all of the students were then re-registered into the appropriate writing course.

- Number of students placed in EGL 097: 0

- $\quad$ Number of students placed in EGL 101: 26

- $\quad$ Number of students placed in EGL 102: 1

3.3.3 Student Placement after the First Day of Class

Although all students took a diagnostic test after completing the transitional summer program, all students had to take another diagnostic test on the first day of class in the fall semester. EGL 101 and EGL 097 instructors must give the diagnostic test to every student on the first day of class.

Number of students placed into EGL 097: 2

Number of students who passed EGL 097: 2

Number of students placed into EGL 101: 24

Number of students who passed EGL 101: 21

Number of students who withdrew from EGL 101: 1

Number of students who failed EGL 101: 2 (passed when they retook it the following semester)

Number of students who passed EGL 102: 1

\section{Discussion}

Despite the importance of writing, too many students do not learn to write well early enough to meet the demands of postsecondary education requirements. As a result, underprepared students are at a great disadvantage when entering postsecondary institutions. Writing interventions had a positive impact of students' perceptions on their own ability to write effectively (Baker et al., 2009). Therefore, a strong need for research focusing on instructional strategies (on 
a secondary and postsecondary level) exists in order to assist basic writers in writing more effectively when transitioning from secondary to postsecondary institutions.

Comparing writing curriculums with student perceptions of weak and strong writing skills could assist in creating content for these transitional programs. Additionally, the creation of transitional writing programs that address the gaps between secondary and postsecondary writing will assist in eliminating the high numbers of students who are required to enroll in remedial writing courses during their first semester at a postsecondary institution. Sacco (2014) found that outcomes for students participating in supplemental writing programs include greater academic success rates, higher rates of retention, and lower rates of attrition.

High attrition and low retention rates are a concern in postsecondary institutions, long-term future issues remain. Proficient writing skills is essential for success in the workplace (Baker et al., 2009). Furthermore, Baker et al., (2009) state that the majority of public and private employers demonstrate that writing proficiency is critical in the workplace and can directly influence hiring and promotion decisions. Writing has become a workplace demand that expands throughout most industries hence, the emphasis placed on writing across the disciplines in postsecondary institutions.

Students may use these academic support programs as both sites of discovery and as remediation. Additionally, a comparison of perceptions and attitudes towards writing using basic writers (including students with learning disabilities, remedial writers, English language learners, and international students), and advanced writers can also provide more accurate perceptions needed to recreate curriculums and transitioning programs in writing within postsecondary institutions. Although transition programs in academic writing have been successful when transitioning students from secondary to postsecondary institutions, the program should be offered and tested on the secondary level as well as the postsecondary level. Additionally, future studies should include a wide range of randomly selected postsecondary students, and not limit participation to students within a specific cohort. Students who participated in the program were given the diagnostic test immediately following completion of the program. However, in order for researchers to examine long-term effects of the transition program, the program should be offered at the high school level.

\section{References}

Applebee, A. N., \& Langer, J. A. (2011). A snapshot of writing instruction in middle schools and high schools. English Journal, 100(6), 14-27.

Baker, S., Chard, D., Ketterlin-Geller, L., Apichatabutra, C., \& Doabler, C. (2009). Teaching writing to as-risk students: The quality of evidence for self-regulated strategy development. Exceptional Children, 75(3), 303-319. https://doi.org/10.1177/001440290907500303

Barbatis, P. (2010). Underprepared, ethnically diverse community college students: Factors contributing to persistence. Journal of Developmental Education, 33(3), 16-20.

Creswell, J. W. (2013). Qualitative inquiry and research design: Choosing among the five approaches ( ${ }^{\text {rd }}$ ed.). Thousand Oaks, CA: Sage Publications.

Fanetti, S., Bushrow, K. M., \& DeWEese, D. L. (2010). Closing the gap between high school writing instruction and college writing expectations. English Journal, 99(4), 77-83.

Graham, S., \& Perin, D. (2007). A meta-analysis of writing instruction for adolescent students. Journal of Educational Psychology, 99, 445-476. https://doi.org/10.1037/0022-0663.99.3.445

Hong, B. S., Ivy, W. F., Gonzalez, H. R., \& Ehrensberger, W. (2007). Preparing students for postsecondary education. Teaching Exceptional Children, 40(1), 32-38. https://doi.org/10.1177/004005990704000104

National Commission on Writing. (2004). Writing: A ticket to work... or a ticket out: A survey of business leaders. Retrieved from www.collegeboard.com

Robinson, H. M. (2009). Writing center philosophy and the end of basic writing: Motivation at the site of remediation and discovery. Journal of Basic Writing, 28(2), 70 - 92.

Sacco, C. M. (2014). An approach to postsecondary writing programs: Evaluating perceptions of self-identified students with disabilities. (Doctoral Dissertation). Retrieved from ProQuest/UMI

TRiO (ASAP) eligibility criteria. (2017). Farmingdale State College. 


\section{Appendix A: Essay Assignment}

\section{$\underline{\text { Topic }}$}

Narrative Essay Initial Assignment

\section{$\underline{\text { Due }}$}

First day of writing component of summer TRiO

\section{$\underline{\text { Assignment }}$}

Write a narrative essay ( $1^{\text {st }}$ person) discussing (a) why you want to go to college, (b) what made you want to go to college, and (c) your hopeful major.

\section{$\underline{\text { Task }}$}

Create an organized essay identifying and discussing the abovementioned components. Be sure your essay has (a) clear and organized ideas, (b) uses transitions between each section, and (c) has an introduction and a conclusion.

\section{Brainstorm Suggestions}

Ideas that may be addressed (but are not limited to) within each section are as follows:

- For the self

- For others

- Financial stability

- Personal experience

- Family \& friends influence

\section{Directions}

- All papers must be double spaced, Times New Roman, 12 font, and 1" margins on each side (already set as standard).

- Only hard copies will be accepted. 


\section{Appendix B: Consent Form}

Title: Transitional Writing Programs for Freshman Entering 4-year Postsecondary Institutions.

\section{Informed Consent to Participate in a Research Study}

We are inviting you to take part in a research study. This form will tell you about the study, but the researcher will explain it to you first. You may ask this person any questions that you have. When you are ready to make a decision, you may or may not sign the form. All of the signed and unsigned consent forms will be collected and held in a sealed envelope until the end of the program; you will receive a copy of an unsigned consent form. Although the assignments are mandatory for the course, the research participation is voluntary.

\section{Why am I being asked to take part in this research study?}

We are asking you to be in this study because you are a traditional incoming freshmen student participating in an academic transitional writing program.

\section{Why is this research study being done?}

The purpose of this research is to identify the effectiveness of writing curriculums and to identify the effectiveness of academic transitional programs.

\section{What will I be asked to do?}

Each student enrolled in the TRiO writing portion is given an initial and a follow-up writing assignment as part of the course; both assignments will be evaluated. If you would like to participate in the research, your essays may be chosen at random, assigned a number (your name will be kept confidential) and the results will be used to measure the effectiveness of the transition program.

\section{Where will this take place and how much of my time will it take?}

This will take place at the current postsecondary institution where you are participating. You will not be asked to give any additional time beyond what will already be assigned to your during the writing class.

\section{Will there be any risk or discomfort to me?}

There is no risk, and there is no discomfort. 


\section{Will I benefit by being in this research?}

There will be no direct benefit to you for taking part in the study. However, information discovered may help with setting up writing programs that can benefit you in the future.

\section{Who will see the information about me?}

The researcher will only know your identity as a participant in this study. Each participant is given a number during the coding process, so any published information will not be connected to your real name. The information obtained (grade on both essays) will be coded onto worksheets, and stored on a password-protected database. All recorded information is locked and stored in a cabinet, and coded information is secured on a database. All written information is destroyed after database input.

\section{Can I stop my participation in this study?}

Your participation in this research is voluntary; you do not have to participate if you do not want to. If you do not participate or if you decide to quit, you will not lose any rights, benefits, or services that you would otherwise have as a student. 


\section{Appendix B: Consent Form}

\section{Who can I contact if I have questions or problems?}

If you have any questions about this study, please feel free to contact XXX at [email] or [phone

\section{Who can I contact about my rights as a participant?}

If you have any questions about your rights in this research, you may contact XXX at [email] or [phone]. You may call anonymously if you wish.

\section{Will I be paid for my participation?}

You will not be paid for your participation in this research.

\section{Will it cost me anything to participate?}

There is no cost to participants.

I agree to take part in this research.

Signature of person [parent] agreeing to take part

Date

Printed name of person above

Signature of person who explained the study to the

Date

participant above and obtained consent

Printed name of person above 